\title{
Child Neglect Protection: Policies and Strategies
}

\author{
Yusnani Hasyimzoem ${ }^{1}$, Yulia Neta ${ }^{2}$, and Bismo Jiwo Agung ${ }^{3}$ \\ \{yus_zoem@yahoo.com ${ }^{1}$, bismojiwoagung05@gmail.com $\left.{ }^{3}\right\}$ \\ Department of Constitutional Law, Faculty of Law, University of Lampung (UNILA) ${ }^{123}$
}

\begin{abstract}
Indonesia is a country with a high number of neglected children. One of the causes of neglect of children in Indonesia is divorce which often motivated by low status of economic, educational and awareness of parents. The aftermath of divorce is often impact on children's situation. In some cases, the consequences of divorce may lead to children neglect which force children to be displaced and some of them ended up living on the streets. There are also possibilities which might turn the children to be perpetrators or victims of crime on the streets. The method used is a normative juridical method and analyzed using qualitative methods. Currently, the government has established a set of rules to prevent child neglect through Indonesia's Constitution 1945, Law Number 23 of 2004 concerning the Elimination of Domestic Violence and Law Number 35 of 2014 concerning Child Protection. The law categorizes child neglect as abandoning households that are prohibited and subject to sanctions for perpetrators. Nonetheless, in reality the act of neglecting households is clearly prohibited as if ignored by the government. The applicable system of fines and prisons is no longer effective, so government should consider other possible strategic policies.
\end{abstract}

Keywords: Neglect; Children; Policy; Protection

\section{Introduction}

\subsection{Background}

Marriage is one way for humans to live their lives and develop. The marriage bond creates a small group consisting of husband and wife or husband and wife and children, or father and child, or mother and child, or blood family in a straight line up or down to the third degree. The ideal family structure is a family consisting of a husband as a family head, a wife as a housewife, and a child as a family member. Family is defined as an important primary group in the community order that is fused from the relationship between men and women. Every family member has their own rights and obligations.

However if one family member violates the rights of other family members and does not carry out their obligations, a problem may arise in the family. The consequences of the problems that arise may trigger an act of violence against other family members or commonly referred to as domestic violence (DV) which often ends in punishment or divorce. Although Indonesia is known as a country with diversity and uphold religious values, it has high divorce rates from year to year; this can be seen in table 1. Below: 
Table 1. Figures on Divorce in Indonesia

\begin{tabular}{lllll}
\hline Year & 2014 & 2015 & 2016 & 2017 \\
\hline Number & 344.237 & 353.853 & 365.654 & 374.516
\end{tabular}

According to authors findings, the high divorce rate in Indonesia is one of the causes of neglect of children. Child neglect might be due to economic instability due to divorced parents or one parent who has a new couple so the child from a previous marriage is abandoned. These phenomenon's may further trigger the increasing number of neglected children along with the number of displaced children in several regions in Indonesia.

Table 2. Number of neglected children in several provinces in Indonesia

\begin{tabular}{cccccc}
\hline Region & West Java & Lampung & East Java & Central Java & $\begin{array}{c}\text { Central } \\
\text { Kalimantan }\end{array}$ \\
\hline Number & 135.787 & 17.636 & 14.702 & 113.859 & 2907 \\
\hline
\end{tabular}

\subsection{Problem Formulation}

1. What are the aftermaths of child neglect to children?

2. What efforts could be done in protecting and rehabilitating children who has neglected?

\subsection{Research Objectives}

1. Knowing the aftermaths of child neglect to children.

2. Finding the new strategic efforts to protect and rehabilitate child who became the victims of children neglect.

\section{Research Method}

This study uses a normative juridical method, namely research that examines a problem based on applicable laws and regulations. The method of assessment used is a qualitative method. The Authors use reports which downloaded from internet and did interview to some parents to support this findings.

\section{Results and Discussion}

\subsection{Children Neglect in Indonesia}

According to Herkutanto, neglect is negligence in providing the necessities of life for someone who has dependence on other parties, especially in the household environment. Neglect acts are defined as any form of disregarding one's obligations and responsibilities in a household according to law, the person has been designated as the holder of responsibility for the life of the person who is in his family environment. One of the factors that may lead to neglect of children is economic factors, where the poverty rate in Indonesia is still high, reaching 25.95 million people or $9.82 \%$ (nine point eighty two percent) of the total population in 2018. Many children who are abandoned by parents are caused by poverty and the economic burden they bear but this may not justify child neglect. 
These are the triggers which may result household neglect:

1. Divorce;

2. Parents are not able to provide needs according to the rights that children have in the form of physical, emotional, educational or medical;

3. Economic conditions that are classified as incapable;

4. Parents with different domiciles with children;

5. One parent who remarries;

6. Don't have a family; or

7. Hectic parents.

Those triggers may be the reason why the children neglect may occur. According to authors' findings, there are parents that so busy to work in order to fulfill their needs but forget to give attention to their children. In addition, the lack of parent awareness and knowledge about parenting might causes children neglect unconsciously. There are various forms of neglect experienced by children in Indonesia such as:

1. Physical neglect

For example, the delay in seeking medical assistance, inadequate supervision and the unavailability of the need for security in the family.

2. Education neglect

Occurs when the child seems to get an appropriate education even though the child may not perform optimally. Over time this might result in children's school performance decreasing

3. Emotional Neglect

This neglect may occur for example when parents do not realize the presence of children when noisy with their partners. Or parents give different treatment and affection among their children.

4. Neglect of Medical Facilities.

This happens because when parents fail to provide medical services for children even though they are financially adequate. In some cases parents, parents give traditional treatment first, if it hasn't healed, then go back to doctor services.

Moreover, these following figures show the data of other forms of child neglect and the detail of the neglected children's status:

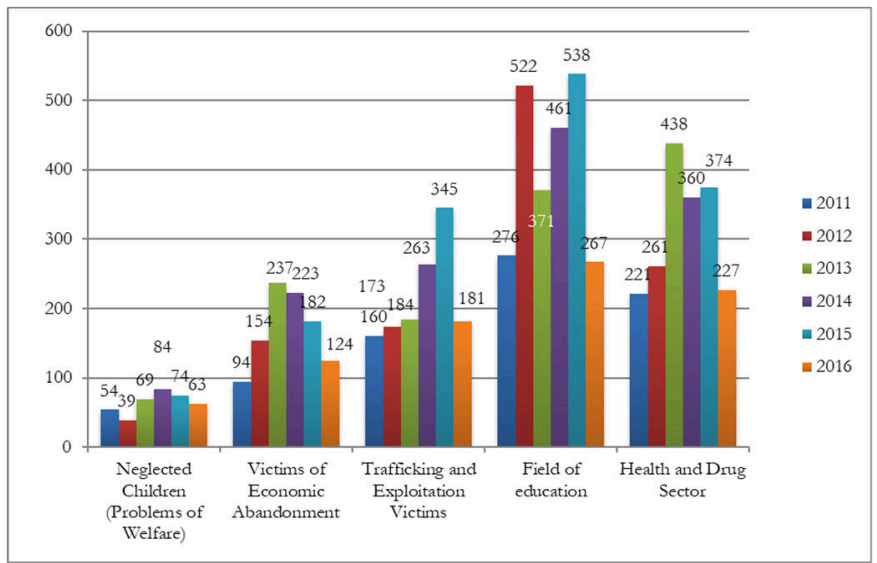

Fig 1. Forms of neglect experienced by children in Indonesia 

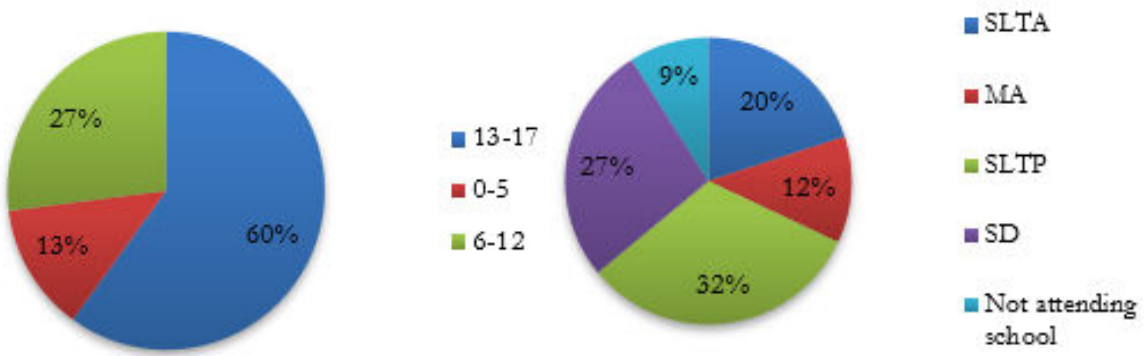

Fig 2. Characteristics of Children Victims of Violence by Age Group and Education Level in Indonesia

As a result of neglect, children who have not been treated might become victims of crime (sexual, physical, exploitation, trafficking) or even become perpetrators of crime (theft, drug abuse, murder and others). Furthermore, abandoned children often become street children. This is what ultimately drives up the number of street children. In August 2017 there were 16,290 street children in Indonesia which very vulnerable to being victims of crime on the streets.

Table 3. Crimes Against Street Children in Indonesia in $\mathbf{2 0 1 7}$

\begin{tabular}{cccccc}
\hline Revocation & Theft & Abuse & Rape & Neglected & $\begin{array}{c}\text { Abandoned } \\
\text { Babies }\end{array}$ \\
\hline 2.117 & 1.244 & 1.115 & 1.108 & 989 & 243 \\
\hline
\end{tabular}

These crimes may occur due to lack of attention and protection of street children by the government and parents. KPAI stated that the reasons for street children are voluntarily become the victims of sexual abuse or prostitution is due to economic factors, where abandoned children need money for their daily needs.

\subsection{The Existing Policy in Protecting Victims of Neglect in Indonesia}

The state guarantees the protection and fulfillment of children's rights in Article $28 \mathrm{~B}$ paragraph (2) of the 1945 Constitution and Law Number 35 of 2014. Child protection in question is all activities to guarantee and protect children and their rights to live, grow , develops, and participates optimally in accordance with the dignity and human dignity, and gets protection from violence and discrimination. Legal protection for neglected children is contained in Article 34 of the 1945 Constitution which states that neglected children are cared for by the State.

Furthermore, efforts to prevent child neglect are regulated in Article 76B of Law Number 35 of 2014 concerning Child Protection which states that, "Every person is prohibited from placing, allowing, involving, and ordering to involve the child in situations of mistreatment and neglect". If one or both parents of children commit neglect, then based on Article 77B of the Law a quo, one or both of these persons may be threatened with imprisonment of a maximum of 5 (five years) and / or a maximum fine of Rp.100.000.000 (one hundred million rupiah). Criminalization is the last choice to solve the problem, but the effects caused by punishment may foster fear and deterrent to the perpetrators.

In addition, living in a household is also regulated in Law Number 23 of 2004 concerning the Elimination of Domestic Violence which regulates the prohibition and punishment of husbands or wives who commit violence against their spouses or children. According to 
Article 49 of the Law a quo, states that everyone who abandons another person in the household sphere is sentenced to a maximum of 3 (three) years imprisonment or a maximum fine of Rp.15.000.000 (fifteen million rupiah).

\section{The New Strategic Policies for the Government in Protecting Child Victims of Household Neglect}

The act of neglecting parents towards their children has an impact on the disruption of child development where lack of attention and affection of parents towards children causes children to have insecurity, fail to develop familiar behavior, experience problems of adjustment in the future and cause psychological effects where children do not know to complain about the problems faced. In addition, there are still many cases of neglect of children that are not visible, and are reported likely because they could not determine who the victims were, and where violence occurred.

Therefore, one way to reduce the rate of neglect of children is by create an empowerment program and increase community awareness and participation in fulfilling the rights to care, health, education, clothing, food and shelter which will be useful to avoid children as victims neglect, exploitation, violence, child pornography and other mistreatment. Moreover, the government is also able to provide socialization and advocacy related to domestic violence, so that there are no more situations where parents who are working unconsciously abandon their children. The government should take concrete steps as soon as possible in responding to neglect actions that are victims of children in the form of:

1. Educating prospective parents or parents who already have children about the consequences and causes of neglect of the household by making subjects on the prevention of violence against children. For the material to be delivered in school, university or offices could coordinate with the Ministry of Education, Ministry of Social Affairs and Ministry of Women Empowerment and Children Protection. Examples such as the class "preparing to become parents". Students will learn about childcare and development, and gain hands-on experience by working with children in a child and preschool education center.

2. Implement Home visitation program which provides services in improving skills and increasing the sensitivity of parents to their child's condition. Such as the policy of making a Consultation Center for Parents which the Program officers are recruited from the community, trained by the center and supervised by professional social workers. Families are visited every month during the prenatal period, weekly for the first 2 months after birth, from that time every 2 weeks to 2 months and then every month until the baby reaches 6 months. The program will later be under the authority of the Ministry of Women Empowerment and Children Protection, the Ministry of Social Affairs in collaboration with the Indonesian Doctors Association. So that young doctors or those who have specialists in the field of maternal and child health could be empowered.

3. In collaboration with the Supreme Court to appeal to the judges in deciding cases of neglecting the household to impose penalties in the form of compensation to the victim with changing the system of fines imposed on neglected persons, where the fine paid will not be entirely included in the state treasury, but will be given all or a portion of the money to the abandoned victims or their guardian. This is due to the core purpose of compensation none other than to develop justice and the welfare of victims as members of the community and the measure of its implementation is by giving victims the opportunity to develop their rights and obligations as human 
beings. So that when referring to the theory, the fine should be partially or wholly given to the victim.

4. In order to maximize the benefits of the compensation for neglected victims, the Ministry of Empowerment and Protection of Women and Children, the Ministry of Social Affairs and the Ministry of Law and Human Rights must provide guidance, training and supervision for the victims in investing the money to improve welfare and continue their life.

5. Furthermore, imprisonment sanctions also do not guarantee resolving this issue. The authors argues that neglect perpetrators could be subject to sanctions in the form of city detention compared to detention centers or prisons that do not allow perpetrators to make a living for victims. As a result, abandoned victims could become increasingly displaced. City prison sanctions could also be accompanied by the obligation of the perpetrator to fulfill all the basic needs of the victim. In order to safeguard the safety of victims from perpetrators who have anger or revenge, the perpetrator could be threatened with a more severe crime if they commit violence against the victim during the probationary period and / or repeat the same thing in the future.

\section{Conclusion and Recommendation}

\subsection{Conclusion}

From the explanation and conditions, finally the conclusions from this paper are:

1. The impact on neglected child victims will be very damaging to their survival. It is evident from the data presented earlier, that victims of neglect are very vulnerable to becoming street children or victims of rape, harassment, or other violence that will damage mental health and physically injure victims.

2. Need for changes which must be taken by law enforcement and policy makers. The existing sanctions did not also reduce the rate of decline in household neglect. Therefore there needs to be alternatives such as sanctions in the form of compensation that require the perpetrators to fulfill all the needs of families who are victims of neglect based on court decisions in order to have binding and coercive power.

\subsection{Suggestions}

1. The government must look for other ways to fulfill the rights and welfare of victims through prevention such as further coordination by the related Ministry about the determination of alternative sanctions imposed on the neglected perpetrators and make curriculum related to self-protection and prevention of neglect of child abuse from an early age coordinated by schools and the Ministry of Social Affairs, Ministry of Education and Ministry of Women's Empowerment and Child Protection.

2. The government must also improve the infrastructure of rehabilitation facilities and provide training and assistance to victims of neglect so that victims could continue to live and have the skills to be able to make a living independently. 


\section{References}

[1] Waluyadi. (2009). Hukum Perlindungan Anak. Bandung:Mandar Maju. pp.1.

[2] Goode J, William. (1995). Sosiologi Keluarga. Jakarta:Bumi Aksara. pp.107.

[3] Ardiansyah, et.al. (2015). Kajian Yuridis Penelantaran Anak Oleh Orang Tua Menurut Prespektif Hukum Indonesia, Jurnal Legalitas Vol. VII No 1. pp. 122.

[4] Joewono, Satria Heryanto. (2016). Pertanggungjawaban Pidana Pelaku Penelantaran Rumah Tangga. Skripsi. Makasar: Program Sarjana Hukum Universitas Hasanuddin. pp.24.

[5] Khairullah, et.al. (2017). Tindak Pidana Penelantaran Dalam Rumah Tangga Di Wilayah Hukum Pengadilan Negeri Kualasimpang, Jurnal Hukum Samudra Keadilan Vol 12 No 1. pp.151.

[6] Kismadewi, Putu Sarasita. (2017). Pertanggungjawaban Pidana Orang Tua Yang Menelantarkan Anaknya Ditinjau Dari Undang-Undang Nomor 35 Tahun 2014 Tentang Perlindungan Anak. Denpasar: Fakultas Hukum Universitas Udayana: pp.1.

[7] Maryandani, Ayu Nadia. (2016). Perlindungan Hukum Terhadap Anak Yang Menjadi Korban Penelantaran Oleh Orang Tua Berdasarkan Hukum Pidana Indonesia. Skripsi. Bandar Lampung: Program Sarjana Hukum Universitas Lampung. pp 27

[8] Natalia, Astrid Fransisca. (2008) Kerugian Yang Diderita Anak Sebagai Akibat Tindak Pidana Penelantaran Oleh Orang Tua. Fakultas Hukum UAJY. pp 10.

[9] Rena, Yulia. (2010). Viktimologi Perlindungan Hukum Terhadap Korban Kejahatan. Jakarta: Sinar Grafika. pp 60).

[10] Retnani, Fauziah. (2013). Pertanggungjawaban Pidana Suami yang Menelantarkan Dan Melakukan Kekerasan Psikis Terhadap Istri Ditinjau Dari Undang-undnag No 23 Tahun 2004 Tentang Penghapusan kekerasan Dalam Rumah Tangga, Jurnal Ilmiah Mahasiswa Universitas Surabaya Vol.2 No.2. pp.10.

[11] Sukardi, Imam. (2013). Tanggung Jawab Negara Terhadap Anak Terlantar Dalam Operasionalisasi Pemerintah Di Bidang Perlindungan Hak Anak. De Jure Jurnal Syariah dan Hukum. Vol 5 No 2. pp.118

[12] Sunandar. (2017). "Tinjauan Terhadap Penelantaran Anak di Kaluku Bodoa Menurut Undang-Undang Republik Indonesia Nomor. 35 Tahun 2014 Tentang Perlindungan Anak". Skripsi. Makassar: Program Sarjana UIN Alauddin Makassar. pp.6.

[13] Syaifullah, Muhammad. (2016). Penelantaran Ayah Terhadap Anak (Dalam Prespektif Hukum Islam dan UU Nomor 23 Tahun 2004 Tentang Penghapusan Kekerasan Dalam Rumah Tangga). Skripsi. Jakarta:Program Sarjana UIN Syarif Hidayatullah. hlm.1.

[14] Varia Peradilan No 303 edisi Februari (2011). Jakarta: Ikatan Hakim Indonesia (IKAHI), pp.18.

[15] KPAI, (2014), Peta Permasalahan Perlindungan Anak di Indonesia dalam http://www.kpai.go.id/artikel/peta-permasalahan-perlindungan-anak-di-indonesia/ diakses tanggal 17 Oktober 2018.

[16] Rostania Dhamayanti, Makalah Penelantaran Anak, 2012, dalam $\mathrm{http}: / /$ rotsania.blogspot.com/2012/11/penelantaran-anak.html diakses tanggal 25 Oktober 2018.

[17] United Nations Sustainable Development Goals, dalam https://www.un.org/sustainabledevelopment/sustainable-development-goals/ diakses tanggal 13 Oktober 2018.

[18] World Health Organization (WHO), Child Abuse And Neglect By Parents And Other Caregivers, $\quad$ dalam https://www.who.int/violence_injury_prevention/violence/global_campaign/en/chap3.pdf diakses tanggal 17 Oktober 2018

[19] Ambaranie Nadia Kemala, Mensos Optimis Target Indonesia Bebas Anak Jalanan Tercapai, dalam https://nasional.kompas.com/read/2017/11/20/18315131/mensos-optimistis-targetindonesia-bebas-anak-jalanan-tercapai diakses 21 Oktober 2018 
[20] Detik Finance, 28 Juli 2018, Data Kemiskinan RI 5 Tahun Terakhir Menurut BPS dalam https://finance.detik.com/berita-ekonomi-bisnis/d-4138150/ini-data-kemiskinan-ri-5-tahunterakhir-menurut-bps diakses tanggal 13 Oktober 2018.

[21] Kanavino Ahmad, (2018), Kasus Eksploitasi Anak Jalanan, Keperawanan Dijual Ke Warga Negara Asing, dalam https://news.detik.com/berita/3797420/kasus-eksploitasi-anak-jalanankeperawanan-dijual-ke-wna-rp-5-juta diakses tanggal 27 Oktober 2018.

[22] KPAI, (2014), Potret Kesenjangan Perlindungan Anak Dari Regulasi Hingga Implementasi dalam http://www.kpai.go.id/artikel/potret-kesenjangan-perlindungan-anak-dari-regulasihingga-implementasi diakses tanggal 17 Oktober 2018.

[23] KPAI, (2014), Potret Kesenjangan Perlindungan Anak Dari Regulasi Hingga Implementasi dalam http://www.kpai.go.id/artikel/potret-kesenjangan-perlindungan-anak-dari-regulasihingga-implementasi diakses tanggal 17 Oktober 2018.

[24] KPAI, (2014), Potret Kesenjangan Perlindungan Anak Dari Regulasi Hingga Implementasi dalam http://www.kpai.go.id/artikel/potret-kesenjangan-perlindungan-anak-dari-regulasihingga-implementasi diakses tanggal 17 Oktober 2018. 